\title{
Flipping EFL University Classes with Blackboard System
}

\author{
Hosam ElDeen Ahmed El-Sawy ${ }^{1}$ \\ ${ }^{1}$ Al-Jouf University, KSA; Damanhour University, Egypt \\ Correspondence: Hosam ElDeen Ahmed El-Sawy, Al-Jouf University, KSA; Damanhour University, Egypt. \\ E-mail: haelsawy@ju.edu.sa
}

Received: October 19, 2017 Accepted: January 2, 2018 Online Published: January 3, 2018

doi: $10.5539 /$ elt.v11n2p31

URL: http://doi.org/10.5539/elt.v11n2p31

\begin{abstract}
This study aims at investigating students' perceptions of flipping EFL classes with the blackboard system. A course was designed to give students an opportunity to experience flipped learning context in developing their reading skills. 49-second year, English department students participated in the project during a complete academic semester consisting of 15 weeks at the university of Al-Jouf, KSA. A detailed questionnaire was prepared and used to enquire students' perceptions. Results of the study revealed that the majority of the participants were willing to use the flipped learning model with blackboard system. The participants provided mixed reasons for this willingness including getting marks, better learning, better communication with the instructor, and having fun. The results also indicated that the majority of participants perceived flipped learning with the blackboard system as a beneficial learning context. The most perceived benefits included improved pronunciation of new vocabulary, facilitating the acquisition of new vocabulary, preparing students for class work, increasing students' time practicing reading at home, reading silently more often, better communication with the instructor and submitting homework easily and quickly. The study also revealed that participants faced some problems when using blackboard in the flipped learning model. Most of these problems were technical and could be overcome with proper training on the use of the system itself. The study recommends the integration of flipped learning in EFL classes. The study also suggests further investigation of the topic with different courses especially theoretical courses taught to university students in English departments.
\end{abstract}

Keywords: flipped learning, EFL, blackboard system

\section{Introduction}

Flipped classroom is a pedagogical technique that is getting popular in recent years. Simply, flipped classrooms or inverted classrooms refer to the idea that what was originally done in class is done at home and what was originally done at home is done in class. In other words, presentation of theoretical ideas and explanations are to be dealt with at home and class time is to be left for practice and active student work. Ekmekci (2017) defined flipped classrooms as a pedagogical approach in which the typical lecture and homework elements of a course are reversed. This idea could be traced back to student-centered instruction in which the focus of the instruction is the student not the teacher and in which the teacher is a guide. Ekmekci (2017) explains that flipped learning transforms classrooms into interactive and dynamic places where the teacher guides the students and facilitates their learning. Lage et al. (2000) and Butt (2014) clarify that flipped learning is one approach that can be used to focus teaching activity on what the student actively does. The approach does this very explicitly, by bringing active student engagement with the material (such as problem solving, case studies, etc., usually in collaboration with other students) directly into the classroom whilst moving more passive activities (such as reading course notes and textbooks and viewing/listening to lectures) outside of the classroom.

\subsection{Theoretical Framework}

Flipped learning could be traced back to communicative language teaching as class time is saved for communication. Li (2015) emphasizes that in EFL flipped classroom, with much of the information in-put session accomplished beforehand, the students can have more interaction and real communication in class using the language, which is the most effective way of language acquisition.

Moreover, flipped classes can be related to the constructivist theory of learning which focuses on students constructing their own knowledge. The flipped classes could also be related to blended learning in which technology plays a vital role in the learning process because in order to allow students to view lectures and 
explanations at home technology has to be used widely and effectively. In the present study, the blackboard system is used to achieve this end.

Li (2015) explains that flipped classroom first appeared in Colorado, America. Jon Bergmann and Aron Sams uploaded their video of PPT and audio instruction online. Students watched these videos at home and the classroom time was saved for those students who had difficulty in doing exercises or experiments. Other instructors in the US, then, North America, and now the whole world quickly tried what they did. It was used in various disciplines in primary, secondary, higher and continuing education. This instructing manner allows the learners to study at their own pace, based on their learning habits and abilities. It ensures the necessary teacher and peer assistance, and respect students' individual difference at the same time. Flipped classes have been used in different areas but still it needs more in-depth research. Webb et al. (2014) and Afrilyasanti et al. (2017) emphasize that although flipped classroom model has been popular, the implementation of flipped classroom in an English as a Foreign Language (EFL) context has not been widely published.

\subsection{The Outline of the Paper}

This paper will start with a review of related literature. Research questions, method, results and discussion will follow. The paper will conclude with recommendations, limitations and suggestions for further research.

\section{Review of Literature}

Research in the area of flipped classrooms covered four main issues. First, the effect of flipped classrooms on students' performance. Second, teachers' perceptions of applying flipped classrooms. Third, students' perceptions of flipped classrooms. Fourth, the factors affecting the application and effectiveness of flipped classrooms.

\subsection{The Effect of Flipped Classrooms on Students' Performance}

Studies revealed contradicting results in relation to the effect of flipped classrooms on students' performance, Some studies revealed significant differences between flipped classes and traditional classes whereas other studies showed that there is no difference between both of them.

For example, Smith (2015) compared two flipped classrooms and two traditional classrooms in fifth-grade. The teacher in the flipped classrooms created learning videos for students to view at home. Students reviewed the videos at home to prepare them for the next day. Students returned to school to complete homework and projects. In the traditional classroom, students received their instruction via lectures and then practiced with the learning content by completing homework outside of the classroom. The study investigated students' achievement and homework completion rates between the students in the flipped classrooms and those students in the traditional classrooms. The findings indicated student achievement did not improve with a flipped learning model. In addition, traditional students had a higher homework completion rate versus the students in the flipped classrooms. Similar results were obtained by Brown's research (2015) which focused on the efficacy of a flipped classroom on undergraduate students' performance when compared to the traditional method of instruction. Student performance was evaluated by comparing exam scores between a traditionally taught course (Fall 2012) and a flipped introductory course (Fall 2013). The study revealed that students in the flipped classroom (Fall 2013) did not exhibit a difference in scores on the final exam when compared to the traditional course (Fall 2012).

Moreover, Mori et al. (2016) explored the pedagogical benefits of flipped online kanji (i.e., Chinese characters used in Japanese) instruction integrated into college-level introductory and intermediate Japanese language courses. Using a quasi-experimental mixed design, the investigation looked at the effects of two instructional approaches: (1) a flip approach in which students learned new characters using online materials prior to class, and (2) the conventional approach in which in-class lectures were followed by printed exercises. During the 2014-2015 academic year, a total of 46 students who were enrolled in introductory or intermediate courses learned 9 to 12 sets of 10 new kanji characters per semester through one lesson per week. Half of the lessons were taught in the flip format, and the other half were taught in the non-flip format. The results showed that introductory students scored better on post-lesson tests in the flip condition than in the non-flip condition only for fall 2014 but not for spring 2015, whereas no statistically significant difference was observed for intermediate students. Within this study, we can find contradictory results. Introductory level students achieved better in one semester while there were no differences in the second semester. In addition, students at the intermediate level seems not to benefit from the flipped classroom model.

On the other hand, a greater number of studies revealed significant differences between flipped classes and traditional classes. For example, Ekmekci (2017) explored the impact of flipped instruction on students' foreign 
language writing skill, which is often perceived as boring, complex and difficult by English as Foreign Language (EFL) learners. The study compared flipped and traditional face-to-face writing classes regarding writing performance. The experimental group consisting of 23 English Language students attending preparatory class were instructed for fifteen weeks through Flipped Writing Class Model while the control group comprising 20 preparatory class students followed traditional face-to-face lecture-based English writing class. Independent and paired samples t-tests were carried out for the analyses of the data gathered through the pre-and post-tests. The results indicated that there was a statistically significant difference between the experimental and control groups in terms of their writing performances based on the employed rubric. It was found that students in the experimental group outperformed students in the control group. On the same track, Leis et al. (2015) conducted a study comparing two English composition courses used with Japanese university students. One course was taught in a traditional way and the other using the flipped classroom. The results showed that those studying in the flipped classroom spent a significantly higher number of hours preparing for class and produced a significantly higher number of words in compositions written in the posttest. The flipped classroom also appeared to result in significantly greater improvements in the writing proficiency of participants. The capability to view explanations of the text as many times as participants wished, as well as opportunities for direct and immediate individual feedback from the instructor for participants in the flipped group are discussed as possible reasons for the salient differences.

In addition, Harvey (2014) conducted a case study to explore the potentials of flipped classrooms in teaching Latin. She compared exam results of two consecutive years. In the year 2012, she used the traditional lecturing method depending on grammar translation method to improve students' Latin skills. Whereas in the year 2013, she used the flipped classroom with most of the lecturing done online while class time was reserved for activities. She found out that there was greater retention and an overall improvement in test scores with flipped classrooms.

Moreover, Zainuddin (2017) aimed to identify the first year college students' learning and experiences in an EFL flipped classroom at the State Islamic University of ArRaniry in Indonesia. 27 students who enrolled in English 2 course participated in his study. The data were collected from diverse sources including questionnaire surveys, focus group discussion, individual interview and observation. The process consisted of three steps: (1) Assemble the raw case; (2) Construct the case record and (3) Report a final case. Results concluded the students in flipped classes had successfully achieved six levels of cognitive domain of Taxonomy or higher-level learning of Bloom's Taxonomy.

In addition, $\mathrm{Wu}$ et al. (2017) examined the impact of an online learning community in a flipped classroom, specifically via mobile platforms, on EFL learners' oral proficiency. Fifty English-majored sophomores enrolled in two oral training classes at a four-year comprehensive university in central Taiwan participated in this study. A mixed method was employed to analyze multiple sources of data, including pre- and post-tests on oral reading and comprehension questions, a questionnaire, and semi-structured focus-group interviews. The results from multiple sources indicated that the flipped learning community not only facilitated meaningful and positive collaboration but also significantly improved the participants' oral proficiency, thus leading to more active engagement in highly interactive learning activities, such as storytelling, dialogue collaboration, class discussion, and group presentations.

Finally, Santosa (2017) aimed at helping students in becoming English as Foreign Language (EFL) competent in-service teachers. Using Flipped Learning, the study utilized four FLIP pillars into EFL learning, namely Flexible environment, Learning culture, Intentional content, and Professional educators. The study employed three instruments: survey, tests, and interview. The result of tests showed a promising students' progress from low to high achievement. The survey showed that students tended to perform deep approaches to learning while findings from the interview provided more interesting phenomena underlying students' motives in their learning approaches, involving dynamic power distance relationship between lecturer and students. On the same track, Köroğlu and Çakır (2017) investigated the effects of Flipped Instruction on pre-service English language teachers' speaking skills. In this study, quantitative data were collected. The data were collected to investigate whether Flipped instruction based syllabus, which was designed specifically for the research, is effective to develop participants' speaking skills. Pre-test and post- tests were administered to both experimental group and control group. The results showed that the experimental group students developed significantly in terms of fluency, coherence, lexical resource, grammar, pronunciation and accuracy skills.

It is clear that most studies found significant differences in favor of the flipped classroom model. However, some contradicting results showed that flipped classroom model has no effect. This indicates that this area needs more research to investigate the effectiveness of applying flipped classrooms model in teaching languages. 


\subsection{Teachers' Perceptions of Flipped Classrooms}

Few studies investigated the perception of teachers of flipped classroom. These studies found out that teachers favored the flipped classroom model and considered it helpful in teaching. For example, Harvey (2014) in his case study exploring the potentials of flipped classrooms in teaching Latin found that the instructor was less constrained by the time needed for in-class lectures and appreciated the benefits of having more time for application and interaction. In addition, Smith (2015) in his research, comparing two flipped classrooms and two traditional classrooms in fifth-grade, collected qualitative data from the teachers regarding the efficacy of the flipped classroom. Teachers reported that the flipped classrooms actively engaged students more in a flipped classroom versus a traditional classroom. This area needs more investigation.

\subsection{Students' Perceptions of Flipped Classrooms}

Students' perceptions of flipped classrooms received the greatest attention of researchers. For example, Smith (2015) in his research, comparing two flipped classrooms and two traditional classrooms in fifth-grade, collected qualitative data from students regarding the efficacy of the flipped classroom. Students acknowledged the flipped classroom provided them more time with the teacher to ask for help, provided challenging work, and allowed students the ability to work at their own pace. The negative impact of a flipped classroom included an array of technological issues that occurred at home. In addition, it was noted that students who are not self-motivated and responsible for their own learning are more likely to struggle in a flipped classroom.

Moreover, Harvey (2014), in his case study exploring the potentials of flipped classrooms in teaching Latin, found that student feedback has been positive. A number of students specifically mentioned that they liked having constant access to the full lecture and printable notes and that the lecture quizzes provided good practice for concepts without being too difficult. A few students complained they would rather hear the lecture in class or they did not like spending time outside of class mastering the new concepts, which is a typical reaction of students who do not have experience with this type of learning.

In the area of teaching EFL writing, Ekmekci (2017) in his study comparing flipped and traditional face-to-face writing classes regarding writing performance, revealed that the great majority of the students in the experimental group held positive attitudes towards Flipped Writing Class Model. Similarly, Afrilyasanti et al (2017) investigated the perceptions of 30 senior high school students who joined an EFL writing class using flipped classroom model. Data were collected by using questionnaires, immediate interview and observations. The results of the research showed that the students revealed that the activities applied in the flipped classroom model helped them write better. They also acknowledged that the videos they watched as well as teacher and peer feedback in their writing process improved their writing ability.

In the area of teaching EFL oral skills, Wu et al. (2017) conducted a study examining the impact of an online learning community in a flipped classroom, specifically via mobile platforms, on EFL learners' oral proficiency and their perceptions. They found out that most students declared that the flipped instruction more effectively and efficiently enhanced their oral performance.

Concerning communication and affective aspects, Zainuddin (2017), in his study, which aimed to identify the first year college students' learning and experiences in an EFL flipped classroom at the State Islamic University of ArRaniry in Indonesia, found out that the majority of students perceived the flipped classroom as highly positive. He also concluded that flipped classrooms enhanced students' enthusiasm for learning the content before coming to class, and provided more opportunities for interaction among peers. Mehring (2015) examined the lived experiences of Japanese university English as foreign language (EFL) students who have taken part in a course taught using the flipped classroom technique. This study used a qualitative approach with a case study design. The study revealed that participants consistently mentioned that the flipped classroom offered them more opportunities to collaborate with classmates. Within instructor-student collaboration, many participants commented that the instructor provided immediate feedback, which helped them to proceed with the activity. Participants also expressed that the flipped classroom appeared to be an enjoyable learning experience. There was a learning curve, but as the participants became accustomed to the course format and witnessed the increased opportunities to communicate in English, they found the flipped classroom beneficial to their learning outcomes. Taking steps to collaborate with classmates, to continue expanding the learning environment with technology, and to interact with classmates and the instructor in English, participants willingly became active learners. Actively engaged in the learning process, as well as learning from their experiences in high school. Their primary reward for these efforts was their ability to use English to communicate effectively, and exchange ideas and information.

The researcher did not find any study in KSA or the Arab region investigating students' perception of flipped 
learning in EFL classes. This is why the present study is important as it seeks to fill this research gap.

\subsection{Factors Affecting the Application of Flipped Classrooms}

In area of studying the factors affecting the application of flipped classrooms, $\mathrm{Yu}$ and $\mathrm{Yu}$ (2017) tried to determine the correlations between the initial EFL proficiency and other variables of the clicker-aided EFL flipped class. The sample was made up of randomly selected 79 participants who received the clicker-aided EFL flipped class for one academic semester. The researchers found that there is a significantly positive relationship between the initial and the final EFL proficiency, motivation levels and cultural awareness. They concluded that the initial EFL proficiency is an essential factor to influence the effectiveness of the flipped class.

Moreover, Allen (2014) found that, when certain conditions are met, flipped classrooms become effective. Conditions include: there must be faculty buy-in; students need to receive active and personalized instruction; abstract ideas must be taught in the classroom; and content taught outside the classroom should be manageable.

Hao (2016) surveyed 387 middle school 7th - graders' flipped learning readiness in their English-as-a-foreign-language (EFL) classrooms and explored the effects of personal characteristics on their readiness levels. Through factor analysis, the researcher found that flipped learning readiness consists of five dimensions: learner control and self-directed learning, technology self-efficacy, motivation for learning, in-class communication self-efficacy, and doing previews. It was found that personal characteristics and individual circumstances, including language beliefs, student perceptions of teacher characteristics, the availability of outside-school support and resources, learning performance, study time and net-surfing time, can make a difference to the levels of the readiness of applying flipped classrooms in EFL settings.

Moreover, Zhai et al. (2017) investigated the contributing factors and driving mechanism accounting for students' perceptions of flipped settings. A students' satisfaction model for the flipped classroom was constructed based on the experiential learning theory. A total of 178 undergraduate students in Mainland China participated in 32-week College English flipped classes, from whom 146 valid questionnaires were obtained. The proposed research model was evaluated through longitudinal surveys followed by the structural equation modeling technique. The results indicated that learners' Prior Learning Experience is a far more significant antecedent for predicting their satisfaction. Furthermore, Perceived Quality (with five first-order dimensions) and Perceived Value are two vital mediators to student satisfaction.

From these studies, we can conclude that the factors that affect the use of flipped classes are divided into two main categories. First, factors related to the students themselves including their initial proficiency, their prior learning experiences, their language beliefs, and their perceptions of the teacher characteristics. Second, factors related to teachers including being convinced with the benefits of flipped classes, their ability to choose suitable content outside and inside class, their ability to make work outside class manageable by students, and their ability to provide students with out-of-school support. These factors need more in-depth investigation together with any other possible factors.

\section{Research Questions}

1) How is students' willingness of using flipped learning with the blackboard system?

2) What are students' reasons for participating in flipped learning activities with the blackboard system?

3) What are students' opinions about the usability of the blackboard system as used in flipped learning?

4) How is students' real engagement in the flipped learning through the blackboard system?

5) What are students' perceived benefits of flipped learning with the use of blackboard system?

6) What are students' overall opinions of their experience in flipped learning with the blackboard system?

\section{Method}

\subsection{Design of the Study}

The study follows a combined qualitative quantitative design. It depends on a combined closed-ended open-ended questionnaire. The closed-ended items provide statistics related to the investigated features while the open-ended items of the questionnaire are presented in a descriptive analytic manner.

\subsection{Participants}

Forty-nine English department students at Al-Jouf University, KSA participated in this project. The participants were students in the Reading 1 course and they voluntarily agreed to participate. Those students who refused to participate were excluded. 


\subsection{The Blackboard System}

The blackboard system is an online educational support system. It allows the teacher to interact with students remotely supporting the learning process. Students get a lot of support through the system. They get information about the instructor, the course and the outline of the course. They get content related to the course. They can also participate in discussion boards created by the teacher for enhancing the learning process. They can receive and submit homework assignments through the system. They sometimes have virtual classes through the system. Moreover, they are assessed through the system. The blackboard system has been incorporated into Al-Jouf University since 2014.

\subsection{The Flipped EFL Class}

The flipped class was applied to the course of Reading 1. The course consisted of six unites. For each unit the teacher provided students with three activities through the blackboard system before they started face-to-face activities in class. The first activity was a recording of an introduction to the unit by the teacher. The aim of this introduction was to build suitable schema to facilitate students' reading of the main reading selection at home. As a response to this activity, students had to answer three background questions about the topic of the unit. The answers were required orally through an audio clip made by students and sent via the blackboard system to the teacher. The second activity was a recording providing students with the key vocabulary items with their meanings and pronunciations. Students had to learn these vocabulary items and record their own pronunciation of them and send this recording through the system. The third activity was guiding questions to motivate students to read at home. The guiding questions were in a word file. Students had to read the reading selection from the book at home and answer the guiding questions. They had to send their answers before the face-to-face session. Face-to-face session time was for exploring the reading more through different activities such as comprehension questions about the main ideas and supporting details of the reading selection, critical thinking activities related to the reading selection and language focus activities related to the reading selection.

\subsection{Instruments}

A questionnaire was prepared by the researcher to investigate students' perceptions of flipping EFL classes using the blackboard system (Appendix 1). The questionnaire consists of 31 items divided into six dimensions. Each dimension covers one of the six research questions stated above. Table 1 shows the distribution of the items to the different dimensions.

A four-point Likert-type scale was used for the closed-ended items from 1 to 27 . Students chose their responses from strongly agree to strongly disagree. Item 28 was a multiple-choice question aiming at identifying the most beneficial aspect of the blackboard system. Items 29 to 31 were open-ended questions aiming at giving participants the opportunity to express any ideas that were not covered in the closed-ended items. The questionnaire was revised by specialists in the field to ensure its internal validity. The calculated reliability of the questionnaire was (Alpha $=.917)$

Table 1. Distribution of the items of the students' perceptions questionnaire of flipping EFL classes using the blackboard system

\begin{tabular}{|c|c|}
\hline Dimension & Items \\
\hline Students' willingness to use the blackboard system in flipped EFL classes & $1-2-3-4$ \\
\hline Students' reasons for participation in blackboard activities in flipped EFL classes & $5-6-7-8-9$ \\
\hline Students' opinion about the usability of the blackboard system in flipped EFL classes & $10-11-12-13$ \\
\hline Students' real engagement in blackboard sections in flipped EFL classes & $14-15-16-17-18-19-20$ \\
\hline Students' perception of the benefits of flipping EFL classes using the blackboard system & $21-22-23-24-25-26-27$ \\
\hline $\begin{array}{l}\text { Students' overall opinion about the usage of the blackboard system in flipped EFL } \\
\text { classes }\end{array}$ & $28-29-30-31$ \\
\hline
\end{tabular}

\subsection{Data Analysis Procedures}

For statistical analysis of the closed-ended items of the questionnaire, the researcher depended on percentages as they give detailed insight for each item. As for the open-ended items, the researcher depended on descriptive analytic presentation. 


\section{Results and Discussion}

5.1 The First Dimension of the Questionnaire, Students' Willingness to Use the Blackboard System in Flipped EFL Classes, Consists of Four Items

Table 2. Percentages of the first dimension of the questionnaire of students' perceptions of flipping EFL classes (Students' willingness to use the blackboard system in flipped EFL classes)

\begin{tabular}{lllll}
\hline Item & $\begin{array}{l}\text { Strongly } \\
\text { Agree }\end{array}$ & Agree & $\begin{array}{l}\text { Disagree } \\
\text { Strongly } \\
\text { disagree }\end{array}$ \\
\hline $\begin{array}{l}\text { I prefer to have homework assignments on the } \\
\text { blackboard system }\end{array}$ & 26.5 & 30.7 & 26.5 & 16.3 \\
$\begin{array}{l}\text { I prefer to receive content related to the course } \\
\text { through the backboard system }\end{array}$ & 28.6 & 44.9 & 14.3 & 12.2 \\
$\begin{array}{l}\text { I like to participate in discussion boards on the } \\
\text { blackboard system }\end{array}$ & 16.3 & 28.6 & 38.8 & 16.3 \\
$\begin{array}{l}\text { I prefer to receive the announcements related to the } \\
\text { course through the backboard system }\end{array}$ & 73.5 & 24.5 & 2 & 0 \\
\hline
\end{tabular}

It is clear from the table that the majority of students were willing to use blackboard as a tool for flipping EFL classes. Receiving announcements through the blackboard system got $98 \%$ agreement $(73.5 \%$ strongly agree and $24.5 \%$ agree). Receiving content through the blackboard system follows with $73.5 \%$ agreement. Having homework assignments through the blackboard system follows with $57.2 \%$ agreement. Finally, participating is discussion boards got about $45 \%$ agreement.

5.2 The Second Dimension of the Questionnaire, Students' Reasons for Participation in Blackboard Activities in Flipped EFL Classes, Consists of Five Items

Table 3. Percentages of the second dimension of the questionnaire of students' perceptions of flipping EFL classes (students' reasons for participation in blackboard activities in flipped EFL classes)

\begin{tabular}{lllll}
\hline Item & $\begin{array}{l}\text { Strongly } \\
\text { Agree }\end{array}$ & Agree & Disagree & $\begin{array}{l}\text { Strongly } \\
\text { disagree }\end{array}$ \\
\hline $\begin{array}{l}\text { I participated in the blackboard activities only to get } \\
\text { the marks }\end{array}$ & 30.6 & 49 & 16.3 & 4.1 \\
$\begin{array}{l}\text { I participated in the blackboard activities because it } \\
\text { provides distinguished learning }\end{array}$ & 20.4 & 36.7 & 23.7 & 10.2 \\
$\begin{array}{l}\text { I participated in the blackboard activities because they } \\
\text { are interesting }\end{array}$ & 14.3 & 28.6 & 34.7 & 22.4 \\
$\begin{array}{l}\text { I participated in the blackboard activities because this } \\
\text { allowed me to connect with my teacher in a better way }\end{array}$ & 26.5 & 26.5 & 36.7 & 10.3 \\
$\begin{array}{l}\text { I participated in the blackboard activities because this } \\
\text { allowed me to connect with my colleagues in a better } \\
\text { way }\end{array}$ & 14.3 & 28.6 & 42.9 & 14.3 \\
\hline
\end{tabular}

It is clear from the table that the majority of students have mixed purposes for participating in the blackboard activities. When asked in item 5 if they participated in the activities only to get the marks, about $80 \%$ responded positively. However, when asked about other purposes in items from 6 to 9 the responded positively for most of the items. About $57 \%$ of the participants declared that they participated in the activities because the activities provided distinguished learning. This percentage gives the idea that a lot of effort has to be done to improve the quality of activities provided through the blackboard. Only $43 \%$ of the participants indicated that the reason for their participation was that the activities through the blackboard were interesting. 53\% of the participants 
declared that the reason for their participation was to have better connection with their teacher while only $43 \%$ indicated that they participated because the activities allowed for better communication with colleagues. This indicates that the communication aspect in blackboard activities needs more enhancement.

5.3 The Third Dimension of the Questionnaire, Students' Opinion about the Usability of the Blackboard System in Flipped EFL Classes, Consists of Four Items

Table 4. Percentages of the third dimension of the questionnaire of students' perceptions of flipping EFL classes (Students' opinion about the usability of the blackboard system in flipped EFL classes)

\begin{tabular}{lllll}
\hline Item & $\begin{array}{l}\text { Strongly } \\
\text { Agree }\end{array}$ & Agree & Disagree & $\begin{array}{l}\text { Strongly } \\
\text { disagree }\end{array}$ \\
\hline $\begin{array}{l}\text { I am good at using the blackboard system } \\
\text { I can deal easily with the content posted on the }\end{array}$ & 30.6 & 42.9 & 12.2 & 14.3 \\
$\begin{array}{l}\text { blackboard system } \\
\text { I answer homework assignments on the blackboard }\end{array}$ & 18.4 & 38.8 & 24.5 & 6.1 \\
$\begin{array}{l}\text { system easily } \\
\text { I have no problems in using the blackboard system }\end{array}$ & 20.4 & 26.6 & 32.6 & 18.4 \\
\hline
\end{tabular}

$73.5 \%$ of the participant considered themselves good at using the blackboard system. $69.5 \%$ of the participants perceived that they could deal with the content posted on the blackboard system easily. This means they could listen to recordings, download them and open word documents on the system. However, only $49 \%$ could post their homework assignments through the system easily. This means that they can receive what is on the system easier than uploading data to the system. This could be due to lack of training in using the system. $47 \%$ of the participants have no problems dealing with the blackboard system. This means that about $53 \%$ of the participants face problems when using the system.

5.4 The Fourth Dimension of the Questionnaire, Students' Real Engagement in Blackboard Sections in Flipped EFL Classes, Consists of Seven Items

Table 5. Percentages of the fourth dimension of the questionnaire of students' perceptions of flipping EFL classes (students' real engagement in blackboard sections in flipped EFL classes)

\begin{tabular}{lllll}
\hline Item & $\begin{array}{l}\text { Strongly } \\
\text { Agree }\end{array}$ & Agree & Disagree & $\begin{array}{l}\text { Strongly } \\
\text { disagree }\end{array}$ \\
\hline $\begin{array}{l}\text { I read the study plan of this course on the blackboard } \\
\text { system }\end{array}$ & 44.9 & 16.4 & 22.4 & 16.3 \\
$\begin{array}{l}\text { I read the teachers' cv posted on the blackboard system } \\
\begin{array}{l}\text { I read the introduction of this course on the blackboard } \\
\text { system }\end{array}\end{array}$ & 42.9 & 32.7 & 16.3 & 8.1 \\
$\begin{array}{l}\text { I read, listened to, or watched every content posted on the } \\
\text { blackboard system }\end{array}$ & 24.5 & 26.5 & 32.7 & 14.3 \\
$\begin{array}{l}\text { I participated in every discussion board related to this } \\
\text { course on the blackboard system }\end{array}$ & 36.5 & 26.5 & 38.8 & 12.2 \\
$\begin{array}{l}\text { In answered all homework assignments on the blackboard } \\
\text { system }\end{array}$ & 24.5 & 22.4 & 44.9 & 8.2 \\
$\begin{array}{l}\text { I participated in every virtual class on the blackboard } \\
\text { system }\end{array}$ & 24.5 & 32.7 & 32.6 & 10.2 \\
\hline
\end{tabular}

The table indicates that the most read sections on blackboard system are the study plan and the teacher's CV as $61 \%$ of the participants read the study plan and $75.6 \%$ read the teachers CV. This could be due to the participants' willingness to be acquainted with the course and the teacher at the beginning of the semester. 53\% 
of the participant read the introduction to the course. $51 \%$ of the participant utilized the content. $49 \%$ of the participant participated in all the discussion boards. $47 \%$ answered all homework assignments. $57 \%$ participated in all virtual classes. In this dimension, the researcher was interested in investigating the percentage of complete participation that is why the items asked about participating in all the activities in each section. This means overall participation is more than the percentages mentioned. The aim was to identify which sections were more interesting for the participants. These sections could be ordered in the following sequence: Teachers' CV, course study plan, virtual classes, introduction to the course, content, discussion boards and homework assignments.

5.5 The Fifth Dimension of the Questionnaire, Students' Perception of the benefits of Flipping EFL Classes using the Blackboard System, Consists of Seven Items

Table 6. Percentages of the fifth dimension of the questionnaire of students' perceptions of flipping EFL classes (students' perception of the benefits of flipping EFL classes using the blackboard system)

\begin{tabular}{|c|c|c|c|c|}
\hline Item & $\begin{array}{l}\text { Strongly } \\
\text { Agree }\end{array}$ & Agree & Disagree & $\begin{array}{l}\text { Strongly } \\
\text { disagree }\end{array}$ \\
\hline $\begin{array}{l}\text { Using the content of this course on the blackboard system } \\
\text { helped me prepare for studying in class }\end{array}$ & 18.4 & 30.6 & 36.7 & 14.3 \\
\hline $\begin{array}{l}\text { Using the content on the blackboard system saved class time } \\
\text { for practicing English more }\end{array}$ & 22.4 & 36.8 & 24.5 & 16.3 \\
\hline $\begin{array}{l}\text { Doing the different activities on the blackboard system } \\
\text { increased the time I practice English outside class }\end{array}$ & 16.3 & 34.7 & 28.6 & 20.4 \\
\hline $\begin{array}{l}\text { Using the blackboard system in this course helped me read } \\
\text { silently at home before going to class }\end{array}$ & 14.3 & 38.8 & 30.6 & 16.3 \\
\hline Using the blackboard system helped me learn the new vocab. & 16.4 & 46.9 & 26.5 & 10.2 \\
\hline $\begin{array}{l}\text { Using the blackboard system helped me pronounce the new } \\
\text { vocab. correctly }\end{array}$ & 20.5 & 46.9 & 22.4 & 10.2 \\
\hline $\begin{array}{l}\text { Using the blackboard system helped me understand the } \\
\text { reading selections better }\end{array}$ & 14.3 & 34.7 & 42.9 & 8.2 \\
\hline
\end{tabular}

The table indicates that the most perceived benefit of flipped learning with the blackboard system is helping students pronounce the new vocabulary items correctly as $67 \%$ of the participants acknowledge this. This was followed by their acquisition of the meanings of new vocabulary items with $63 \%$. This may be due to the uploading of a recording of all key vocabulary items of each chapter on blackboard. This enabled students to listen to vocabulary items more than once. Consequently, they got the meaning and pronunciation correctly and easily. Saving class time for more practice of language came next with $59 \%$. This is consistent with the main purpose of applying flipped learning, which is saving class time with technology. Helping students to read silently at home came next with $53 \%$. This was great as students before applying flipped learning almost never read the text at home before class. This means applying flipped learning achieved one of the core skills of reading which is reading silently and answering related questions. This could be due to the activity of guiding questions that students needed to answer and submit on blackboard before coming to class. Increasing the time of practicing English outside class came next with 51\% agreement. Again, this is a wonderful result as the teacher found great difficulty getting students to practice the language outside class before applying flipped learning. Helping students to prepare for class and helping them understand the reading selection better came last with $49 \%$ agreement. The overall perception of flipped learning with the blackboard system as acknowledge by students is positive and is consistent with the philosophy of flipped learning and previous studies.

5.6 The Sixth Dimension of the Questionnaire, Students' Overall Opinion about the Usage of the Blackboard System in Flipped EFL Classes, Consists of Four Items

This dimension was dealt with differently from the previous dimensions. The first item (item 28) was a multiple-choice questions investigating students' perception of the most beneficial section of blackboard. The last three items asked the participants questions that allowed them to answer freely and express themselves in an open-ended manner. 
Results of item 28 revealed that $33 \%$ of the participants perceived the content section as the most beneficial section. Discussion boards and homework assignments came second with $25 \%$ each. Virtual classes came last with $17 \%$. Students perceived the content section as the most beneficial section as through it they received the recorded files for introduction and vocabulary. Moreover, they received the word document of guiding questions. Discussion boards and homework assignments allowed them to respond to the content. Virtual classes came last as they resemble face-to-face interaction and consequently they give students nothing new.

Item 29 investigated the difficulties that students faced during the project. Students mentioned the following difficulties. They are ordered based on their frequency.

- Uploading homework

- Downloading content

- Logging to the system or one of its sections

- $\quad$ Recording homework

- System hanging

- Slow internet and lack of consistent internet access

- Unsuitable time of virtual classes

Item 30 investigated students' perceptions of the most important benefit. Students revealed the following benefits. They are ordered based on their frequency.

- $\quad$ Easiness and speed of submitting homework

- Pronunciation of new vocabulary

- Learning new vocabulary

- Advertisements about lectures and exams

- Preparing students for class work

- $\quad$ Saving class time for more practice

- Better opportunities for communication with the teacher

- $\quad$ Reading at home

These results are consistent with the results of the fifth dimension, which is the perceived benefits of flipped learning with the blackboard presented above.

Item 31 asked students for any further suggestions for improving the flipped learning class. They provided some suggestions including:

- Simplifying the uploading of material to the blackboard (technical issue)

- Giving students more opportunities for resending homework responses

- Using interactive homework

- Assigning more marks for blackboard work

- Canceling virtual classes

The majority of participants' overall view of flipped learning with the blackboard system was positive.

\section{Conclusion and Recommendations}

The study revealed that the majority of participants perceive flipped learning with the blackboard system as beneficial in language learning. The most perceived benefits include improvement in a lot of aspects such as pronunciation of new vocabulary, learning new vocabulary, preparing students for class work, saving class time for more practice, better opportunities for communication with the teacher, reading at home, and better reading comprehension. The study revealed also that the majority of participants are willing to use flipped learning with the blackboard system and that they have different reasons for this willingness. The study also revealed that students faced some challenges when using flipped learning with blackboard system. Most of these challenges are technical problems, which could be overcome, with more training on using the blackboard system especially through mobiles.

Theoretically, this study filled a research gap. Most of the studies that dealt with students' perceptions of flipped learning focused on positive and negative perceptions while the present study provides detailed insight in 
students' willingness of using flipped learning, their reasons for participation, their level of engagement, the perceived benefits, their preferences when using this type of learning and the challenges they faced. Moreover, the study filled another gap, as it incorporates a set technological system (blackboard system) in the flipped classroom. In addition, the study is the first in the Arab world in this area. This gives more insight of students' perception of flipped learning in a different context.

Practically, this study provides teachers and university staff with detailed insight in students' perceptions EFL flipped classes. This could encourage teachers and university staff to incorporate flipped leaning in language instruction programs. This also could help them overcome the challenges that face students when using flipped learning.

\section{Limitations of the Study}

The study was limited to one course only which is Reading 1 ; consequently it is difficult to generalize the results to other fields of language learning such as listening, speaking or writing without further investigation.

\section{Suggestions for Further Research}

- Investigating experimentally the impact of using flipped EFL classes in reading instruction.

- Investigating university staff's perception of using flipped EFL classes

- Investigating the dynamics of student-teacher relationship when using flipped classes

- Investigating the possibilities of using flipped EFL classes for improving the four language skills

- Investigating the possibilities of using flipped EFL classes in teaching linguistics and literature courses

- Investigating the different factors that affect the use of flipped EFL classes

\section{Acknowledgements}

This research was funded by Al-Jouf University, KSA. Research project no. (401/37)

\section{References}

Afrilyasanti, R., Cahyono, B., \& Astuti, U. (2017). Indonesian EFL students' perceptions on the implementation of flipped classroom model. Journal of Language Teaching and Research, 8(3), 476-484. https://doi.org/10.17507/jltr.0803.05

Allen, S. (2014). Shifting the instructional paradigm: Articulating a set of current practices in flipped library instruction. Tennessee Libraries, 64(3).

Brown, K. (2015). Evaluating student performance and perceptions in a flipped introductory undergraduate biology classroom. A thesis presented in partial fulfillment of the requirements for the degree of Master of Science University of Massachusetts Boston.

Butt, A. (2014). Student views on the use of a flipped classroom approach: Evidence from Australia. Business Education \& Accreditation, 6(1), 33-43.

Ekmekci, E. (2017). The flipped writing classroom in Turkish EFL context: A comparative study on a new model. The Turkish Online Journal of Distance Education, 18(2), 151-167. https://doi.org/10.17718/tojde.306566

Hao, Y. (2016). Middle school students' flipped learning readiness in foreign language classrooms: Exploring its relationship with personal characteristics and individual circumstances. Computers in Human Behavior, 59, 295-303. https://doi.org/10.1016/j.chb.2016.01.031

Harvey, S. (2014). The flipped Latin classroom: A case study. Classical World, 108(1), 117-127. https://doi.org/10.1353/clw.2014.0060

Köroğlu, Z., \& Çakır, A. (2017). Implementation of flipped instruction in language classrooms: An alternative way to develop speaking skills of pre-service English language teachers. International Journal of Education and Development using Information and Communication Technology, 13(2), 42-45.

Lage, M., Platt, G., \& Treglia, M. (2000). Inverting the classroom: A gateway to creating an inclusive learning environment, Journal of Economic Education, 31(1), 30-43. https://doi.org/10.1080/00220480009596759

Leis, A., Cooke, S., \& Tohei, A. (2015). The effects of flipped classrooms on English composition writing in an EFL environment. International Journal of Computer-Assisted Language Learning and Teaching, 5(4), 1-15. https://doi.org/10.4018/IJCALLT.2015100103

Li, R. (2015). Computer technology and EFL teaching in China. Applied Mechanics and Materials, 701, 
$1267-1270$.

Mehring, J. (2015). An exploratory study of the lived experiences of Japanese undergraduate EFL students in the flipped classroom. Pepperdine University, ProQuest Dissertations Publishing, 3680237.

Mori, Y., Omori, M., \& Sato, K. (2016). The impact of flipped online Kanji instruction on written vocabulary learning for introductory and intermediate Japanese language students. Foreign Language Annals, 49(4), 729-749. https://doi.org/10.1111/flan.12222

Santosa, M. (2017). Learning approaches of Indonesian EFL Gen Z students in a Flipped Learning context. Journal on English as a Foreign Language, 7(2), 183-208.

Smith, J. (2015). The efficacy of a flipped learning classroom, A Dissertation Presented in Partial Fulfillment of the Requirements for the Degree Doctorate of Education in Curriculum and Instruction, McKendree University, USA. Published by ProQuest LLC.

Webb, M., Doman, E., \& Pusey, K. (2014). Flipping a Chinese university EFL course: What students and teachers think of the model. The Journal of Asia TEFL, 11(4), 53-87.

Wu, W., Chen Hsieh, J., \& Yang, J. (2017). Creating an online learning community in a flipped classroom to enhance EFL learners' oral proficiency. Educational Technology \& Society, 20(2), 142-157.

Yu, Z., \& Yu, L. (2017). Correlations between learners' initial EFL proficiency and variables of clicker-aided flipped EFL class. Education and Information Technologies, 22(4), 1587-1603. https://doi.org/10.1007/s10639-016-9510-0

Appendix 1. Questionnaire of Students' Perceptions of flipping EFL classes using the blackboard system (Prepared by the researcher)

\begin{tabular}{|c|l|l|l|l|}
\hline \multicolumn{1}{|c|}{ Item } & $\begin{array}{c}\text { Strongly } \\
\text { Agree }\end{array}$ & Agree & Disagree & $\begin{array}{c}\text { Strongly } \\
\text { disagree }\end{array}$ \\
\hline $\begin{array}{c}\text { 1. I prefer to have homework assignments on the blackboard } \\
\text { system }\end{array}$ & & & & \\
\hline $\begin{array}{c}\text { 2. I prefer to receive content related to the course through the } \\
\text { backboard system }\end{array}$ & & & & \\
\hline $\begin{array}{c}\text { 3. I like to participate in discussion boards on the blackboard } \\
\text { system }\end{array}$ & & & & \\
\hline $\begin{array}{c}\text { 4. I prefer to receive the announcements related to the course } \\
\text { through the backboard system }\end{array}$ & & & & \\
\hline $\begin{array}{c}\text { 5. I participated in the blackboard activities only to get the } \\
\text { marks }\end{array}$ & & & & \\
\hline $\begin{array}{c}\text { 6. I participated in the blackboard activities because it } \\
\text { provides distinguished learning }\end{array}$ & & & & \\
\hline $\begin{array}{c}\text { 7. I participated in the blackboard activities because they are } \\
\text { interesting }\end{array}$ & & & & \\
\hline $\begin{array}{c}\text { 8. I participated in the blackboard activities because this } \\
\text { allowed me to connect with my teacher in a better way }\end{array}$ & & & & \\
\hline $\begin{array}{c}\text { 9. I participated in the blackboard activities because this } \\
\text { allowed me to connect with my colleagues in a better way }\end{array}$ & & & & \\
\hline 10. I am good at using the blackboard system & & & \\
\hline $\begin{array}{l}\text { 11. I can deal easily with the content posted on the blackboard } \\
\text { system }\end{array}$ & & & & \\
\hline $\begin{array}{l}\text { 12. I answer homework assignments on the blackboard system } \\
\text { easily }\end{array}$ & & & & \\
\hline \begin{tabular}{l} 
13. I have no problems in using the blackboard system \\
\hline
\end{tabular} & & & & \\
\hline
\end{tabular}


14. I read the study plan of this course on the blackboard system

15. I read the teachers' cv posted on the blackboard system

16. I read the introduction of this course on the blackboard system

17. I read, listened to, or watched every content posted on the blackboard system

18. I participated in every discussion board related to this course on the blackboard system

19. In answered all homework assignments on the blackboard system

20. I participated in every virtual class on the blackboard system

21. Using the content of this course on the blackboard system helped me prepare for studying in class

22. Using the content on the blackboard system saved class time for practicing English more

23. Doing the different activities on the blackboard system increased the time I practice English outside class

24. Using the blackboard system in this course helped me read silently at home before going to class

25. Using the blackboard system helped me learn the new vocab.

26. Using the blackboard system helped me pronounce the new vocab. correctly

27. Using the blackboard system helped me understand the reading selections better

28. The most beneficial section on the blackboard system for language learning is .......
a) The content (
b) The discussion boards (
)
c) Homework assignments (
d) Virtual classes ( )

29. What are the difficulties that faced you when using the blackboard system?

30. What is the most important benefit of the blackboard system for you and why?

31. Write any remark or suggestions that you want to add about the usage of the blackboard system in this course.

Note: all items are related to your use of the blackboard system in Reading 1 course not other courses.

\section{Copyrights}

Copyright for this article is retained by the author(s), with first publication rights granted to the journal.

This is an open-access article distributed under the terms and conditions of the Creative Commons Attribution license (http://creativecommons.org/licenses/by/4.0/). 